\title{
Commercial Prototype of Borobudur Chair Towards Hilirisasi
}

\author{
Rahmanu Widayat ${ }^{1}$, Anung B. Studyanto ${ }^{2}$, and Lu'lu Purwaningrum ${ }^{3}$ \\ ${ }^{123}$ Department of Interior Design, Faculty of Arts and Design, Sebelas Maret University, \\ Surakarta, Indonesia \\ ${ }^{1}$ rahmanuwidayat@staff.uns.ac.id, 2anungbs@staff.uns.ac.id, \\ ${ }^{3}$ lulu_purwaningrum@staff.uns.ac.id
}

\begin{abstract}
The problem with the title of this article is how the Borobudur Chair model can be commercialized and brought closer to its users or downstream. The method used is the creation of new designs, collaboration with the furniture industry, and the cultural approach of its users. The creation of new designs by making several design alternatives, cooperation with industries that are able to produce in large quantities, easy distribution, and sell at low prices. Associated with a cultural approach becomes important considering the aesthetic capital of the designer with different users. In the future related to the marketing of this Borobudur chair prototype through its maker industry, it can be included in international scale exhibitions to reach more consumers.
\end{abstract}

Keyword: hilirization, commercial, Borobudur chair, prototype

\section{INTORDUCTION}

The commercial prototype of the Borobudur chairs towards hilirization can be explained as several things, such as prototype, initial products or examples with dimensions and ergonomics standards of a chair model created with design considerations. Based on exploratory experiments on the development of the design of the Borobudur chair with aèng concept proved that the design work that was originally functional can be transformed into a work of art because of the freedom of interpretation of form changes and the concept of aèng, such as distortion or refraction and destruction[1]. Commercial chairs aimed at gaining profits in the sales process. The Borobudur chair is the result of the reconstruction of various types of chairs contained in the relief of the Borobudur temple, then, one of the reliefs is taken as an example in the furniture industry. Chairs have the meaning as sitting facilities withstand elements supported by chair legs, has one or more chairs and has a backrest and some are equipped with armrests. Chairs in the context of art sociology have several levels related to the use including high art, folk art, and popular art[2]. Some chairs are sociologically used by the upper class, ordinary people, and also used because of trends.

Towards hilirization means moving to a direction closer to the results of research and discovery to its users. Users of chair products are the general public, private and government institutions, small industries, medium industries, or large industries. The problem of the commercial prototype of Borobudur chairs heading hilirization is how to create a new chair in which the source of inspiration is the research results of the commercial Borobudur chairs reconstruction or Borobudur chairs that have an affordable price and are desirable by the wider community. The most important thing is the easiness of the distribution. 


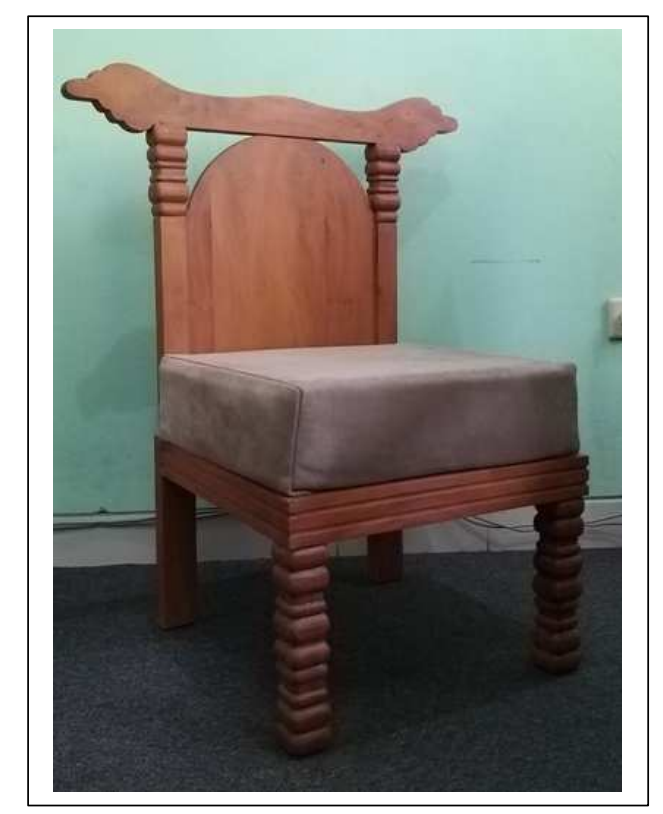

Figure 1. Reconstruction of Borobudur Chair Phase 2 (2018), Research Teams involve Rahmanu Widayat and Anung B. Studyanto

\section{METHODS}

The method used was the creation of a new alternative design with the reference of Borobudur chair. Producing, in this case, means making a large amount of mass production, and marketing it to the wider community as a user. Design methods in a commercial context referring to the notion of design is a vehicle for implementing innovations in various industrial and business activitie business, in this case, is gain benefit from the sold product[3]. Furthermore, it would be more appropriate to cooperate with the furniture industry to produce large quantities. The marketing or the community target used a cultural approach because the consumer has a pattern of behavior that is passed down over the generation in a society or culture that can be said as customs[4]. This is to reduce the gap in aesthetic understanding between designers and users.

\section{RESULT AND DISCUSSION}

Design considerations were done by making several alternative designs inspired by the Borobudur chair. Designs created should be able to reflect the culture of the current time we live today. This corresponds to Solichin Gunawan's opinion that design is a reflection of the culture [5]. This is what designers interpret, so the role of designers is very important related to the creation of chairs in accordance with the era. 
Collaboration with the furniture industry is with CV. Vina Arya Furniture, Manufacturer \& Exporter of Fine Furniture, Jl. Raya Karangjati KM 26 Kec. Klepu, Ungaran 50552, Central Java Indonesia which has complete machine tools and master marketing. In an industrial context, it can also learn from Michael Thonet who is famous for his chair product which is a combination between the hand-made and a machine[6]. In 1830, Michael Thonet was successful as a wood furniture entrepreneur because he had a unique chair concept.

Michael Thonet, from the small town of Boppard in Germany, had a unique product concept. He produced the wooden chairs made in large quantities, sold at low prices, and could be transported easily when exported. He abandoned the conventional idea of making wooden chairs using a system of pegs, dowels, and pivots. Parts of the chair, in the form of pieces of wood, formed and joined with wood glue. Thonet invented wood processing techniques by forming and bending wood. The chair with this technique was known as "Bugholzstuhl" and he got a huge success until when Thonet died in 1871. He became the largest wood producer in the world. Because of the huge popularity of this chair, the name "Thonet chair" became a well-known trade name[7]. Based on the above opinion, the benefits of cooperation with the furniture industry include 1) can make chairs in large numbers; 2) low prices can be reached by the wider community; 3) distribution of goods is easy because the design has been considered related to transportation.

The cultural approach is related to marketing factors so that products are more easily accepted by the intended community since a product will have consequences to influence user behavior[8]. Cultural forms contain concepts, behavior patterns, and products in the form of objects[9]. Each community group has a concept that is shared, a pattern of behavior that has been passed down from over the generations, and has a product of the results of their creative processing. Society has its aesthetics that is sometimes different from the aesthetics of the designer, even the aesthetics related to the objects used are not the main consideration[10].

\section{CONCLUSION}

Based on the description above, it can be concluded that the commercial prototype of Borobudur chairs towards hilirization aims at designing several alternative chairs in which ideas are from Borobudur chairs and reaching a commercial level in collaboration with the furniture industry to produce more chairs, have cheaper prices, and have effective and efficient distribution. Cultural considerations are important to reduce the aesthetic understanding gap between the designer and the user community. Further research is expected to involve new Borobudur chair products in international scale exhibitions collaborated with. It is also expected that the industry has wider marketing and more consumers.

\section{REFERENCES}

[1] Widayat R, Studyanto AB. Exploration of Design Development Borobudur Chair with The Aeng Method (strange). 41(Bcm 2017): 4-7. 2018.

[2] Hauser A. The Sosiology of Art. Northcott KJ, editor. Chivagi: The University of Chicago; 1982.

[3] Sachari, Agus. Sunarya YY. Sejarah dan Perkembangan Desain dan Dunia Kesenirupaan di Indonesia. Bandung: Penerbit ITB. 2002.

[4] Departemen Pendidikan dan Kebudayaan RI. Kamus Besar Bahasa Indonesia. Jakata: Balai Pustaka. 1996.

[5] Sachari, Agus. Sunarya YY. Desain dan Dunia Kesenirupaan Indonesia dalam Wacana Transformasi Budaya. Bandung: Penerbit ITB.2001.

[6] Haskett J. Desain Industri. Agus Sachari (editor). Bandung: CV. Rajawali. 1986. 
[7] Widagdo. Desain dan Kebudayaan. Bandung: Penerbit ITB. 2005.

[8] Sachari A. Sosiologi Desain. Bandung: Penerbit ITB. 2002.

[9] Koentjaraningrat. Kebudayaan Mentalitas dan Pembangunan. Jakarta: PT. Gramedia; 1984.

[10] Laurens JM. Arsitektur dan Perilaku Manusia. Jakarta: PT. Grasindo. 2004. 